\title{
GATA1 Gene
}

National Cancer Institute

\section{Source}

National Cancer Institute. GATA1 Gene. NCI Thesaurus. Code C28575.

This gene is involved in erythropoiesis and transcriptional activation. 